\title{
Self-Governance for Sustainable Global Supply Chains: Can it Deliver the Impacts Needed?
}

\author{
Walter J.V. Vermeulen* \\ Utrecht University - Copernicus Institute of Sustainable Development, Utrecht, Netherlands \\ Stellenbosch University - Sustainability Institute, Stellenbosch, South Africa
}

\section{ABSTRACT}

The world community convened in Rio de Janeiro in June 2012 for the third UN Conference on Sustainable Development. We are, however, increasingly facing major persistent threats, which despite being known for a few decades are still far from being solved - or are even still increasing. On the individual business level, this has four major implications: increased social pressures; possible reputational damage; exposure to resource wars; and front-running competitors adjusting their value chain strategies. In supply chain governance this leads to four main types of strategies: do it yourself; join forces; the ${ }_{5} \mathrm{C}$-approach and harmonising. The key question is: is this sufficient? Imagine 2022 - where will we be 10 years after Rio 2012 ? Is a rapid and structural transition to a circular and fair global economy possible, using this path of self-governance for products traded in the global economic arena? This will strongly depend on four key factors: rapid growth of consumer demand; 'all-inclusiveness' of these supply chain governance approaches; successful uplifting production practices of all suppliers; and addressing the major issues of unsustainability. Here we see various serious weaknesses, like the lack of third-order evaluation and biases causing some of the more recent issues to be overlooked and less visible supply chains. The challenge is to develop a form of 'meta'-governance, including new approaches by governments, combining public policy strategies with the demonstrated virtues of self-governance. Copyright (C) 2013 John Wiley \& Sons, Ltd and ERP Environment

Received 12 September 2012; revised 16 March 2013; accepted 26 March 2013

Keywords: sustainable supply chains; global trade; certification; governance

\section{Introduction}

N THE SUMMER OF 2012 THE WORLD COMMUNITY AGAIN CONVENED IN RIO DE JANEIRO FOR THE THIRD UN CONFERENCE ON Sustainable Development. One of the major issues was the transition to a circular and fair global economy. During the first two events in 1992 and 2002 the final document included a statement about unsustainable patterns of production and consumption, stating that 'the major cause of the continued deterioration of the global environment is the unsustainable pattern of consumption and production, particularly in industrialised countries, which is a matter of grave concern, aggravating poverty and imbalances' (UNCED, I992, p. I8). Since the ink of this quote

*Correspondence to: Walter Vermeulen, Utrecht University - Copernicus Institute of Sustainable Development, PO Box 80115, Utrecht, Utrecht 3508TC, Netherlands. E-mail: w.j.v.vermeulen@uu.nl 
dried, the world economy has been through various phases of accelerating growth and trade. Despite the current crisis and some ups and downs in national growth rates, this is still the overall picture. The process of outsourcing and transferring manufacturing from the Western world to cheap labour and 'pollution haven' countries has restructured our national economies, as well as the global distribution of production. Basic production in Europe decreased, while trade flows between Europe and North America and developing countries have grown between I980 and 2010 by 500 to $600 \%$, with global trade in this period growing from $\$ 2.3$ trillion to $\$ 15.4$ trillion (plus $650 \%$ ). Trade with Asia has especially boomed in this period (see Figure I). As just one example; global trade in cotton grew in this period of three decades by a factor of nine in \$ volume and a factor of $\mathrm{I} .8$ in weight volume (WTO ITS, $20 \mathrm{O} 2$ WTO ITS).

Meanwhile, as a world community, we are increasingly facing major persistent threats, which have already been known about for a few decades (WCED, I987), but are still far from being solved or are even still increasing. These are:

- continuing population growth, linked to poverty and food security (Caldwell, 2004; UN DESA, 2004; UN Population Division, 20I0; FAO, 20II);

- this globally further pushes urban sprawl and growth of unhealthy megacities (UNEP, 20II);

- an increasing volume of human consumption, which is enabled by still very inefficient modes of production and (also as a result of the first two threats) accelerating depletion of crucial mineral and water resources (Fischer-Kowalski and Swilling, 20II);

- and as an essential part of that, the carbon-based energy system which results in climate change and its additional ecological and social impacts (IEA, 20IO).

These are just a part of a far wider scope of effects on our global ecosystems and biodiversity losses (UN Millennium Ecosystem Assessment, 2005).

In the recent United Nations Environment Programme (UNEP) report titled 'Decoupling Natural Resource Use and Environmental Impacts from Economic Growth', the recent dramatic changes in long-term economic trends are shown. While until the beginning of the 2ist century there was a continuous downward trend in commodity prices on the global market, in the last few years we have seen a strong shift towards rising prices (Fischer-Kowalski and Swilling, 20II, p. I3).

There is a fairly wide scholarly consensus about the main routes for solutions, including (Escobar, I996; Hueting \& Reijnders, I998; Robinson, 2004; Dasgupta, 2010) including:

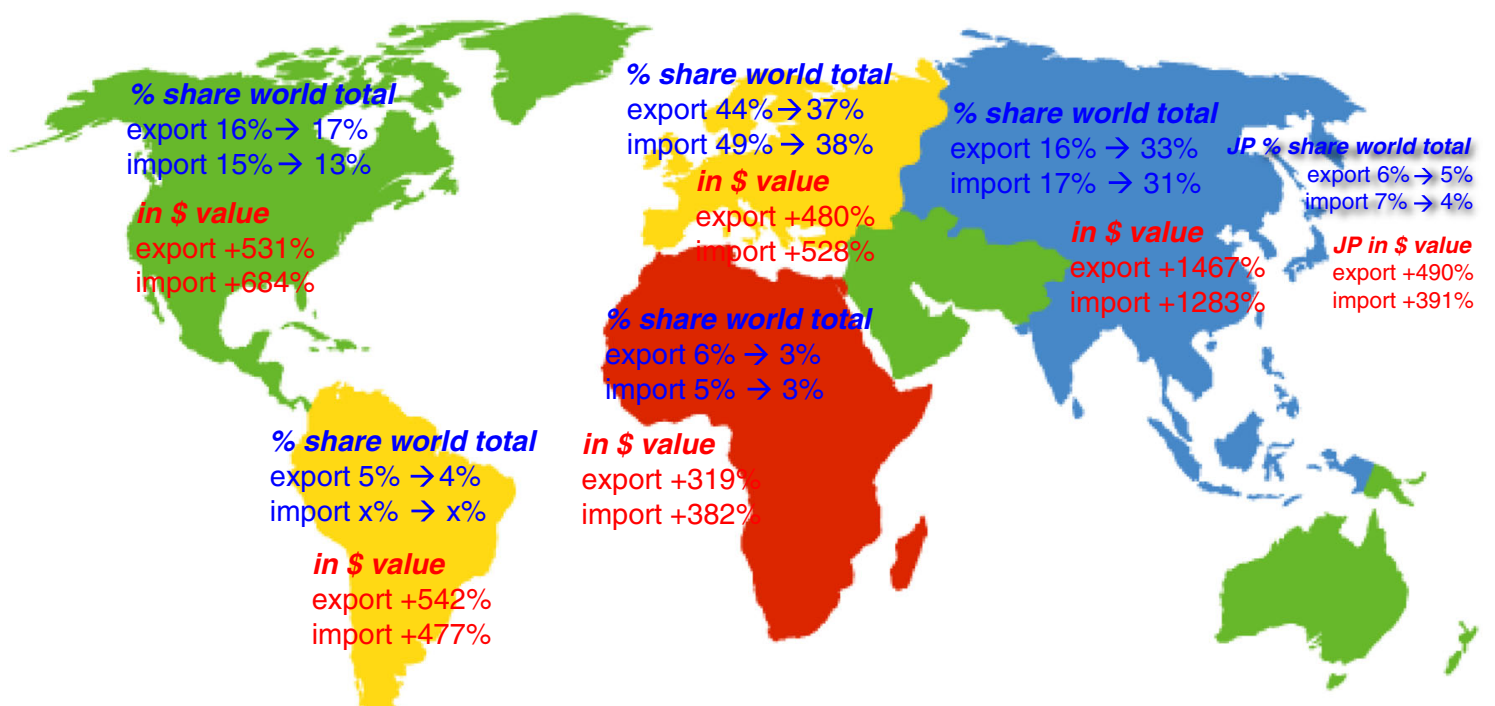

Figure 1. Changes in world trade volume 1980-2010. (volume in $\$$ and share in \%) (source WTO-ITS) 
- the creation of a circular economy, reducing its dependency on virgin resources;

- shifting from a carbon-based energy system to renewable energy resources;

- addressing poverty with the UN Millennium Goals (UNDP, 20I0);

- poverty oriented production approaches, like bottom of the pyramid (BoP) (Schrader et al. 20I2), and;

- addressing institutional causes of unsustainability in the globalized economy (UNEP, 20II).

In this context the newly emerging economies, big and small, are importunately demanding their 'fair' share of the Earth's wealth and resources. The essential question then is: who could bring any solid argument to prevent them from also living the affluent lifestyle that we in Europe have been practising over the last decades? This implies maximizing eco-efficiency both here in Europe and everywhere else simultaneously.

\section{What are the Implications of These Global Macro-Trends for Business?}

When we move from these global macro-trends down to the level of individual businesses, we can see four major implications:

I. increased social pressures for sustainable production practices;

2. possible resulting reputational damage;

3. exposure to resource wars, increased sourcing competition, and;

4. frontrunners adjusting their value chain strategies.

\section{Increasing Pressures}

Forces in civil society are increasingly - most certainly in western Europe and North America - amplifying their pressure on international firms. With the internet making connections between civil society groups everywhere in the world easy and affordable, activists can easily contact each other; incidents of social exploitation and environmental devastation are rapidly shared. Many environmental and development nongovernmental organizations (NGOs) have included fair supply chain practices in their core activity agenda (see Figure 2). With their limited resources they usually target the largest and most well-known consumer product firms like Apple and Nike, as well as leading retailers. We see two main strategies on this front: either adversarial public campaigning or collaborative strategies aiming at implementing sustainable supply chain management by leading firms.

The first strategy rests on the high willingness of major news media (television, newspapers and new social media) to promulgate the strong narratives of unfairness in the 'global village'. For example, in recent years in
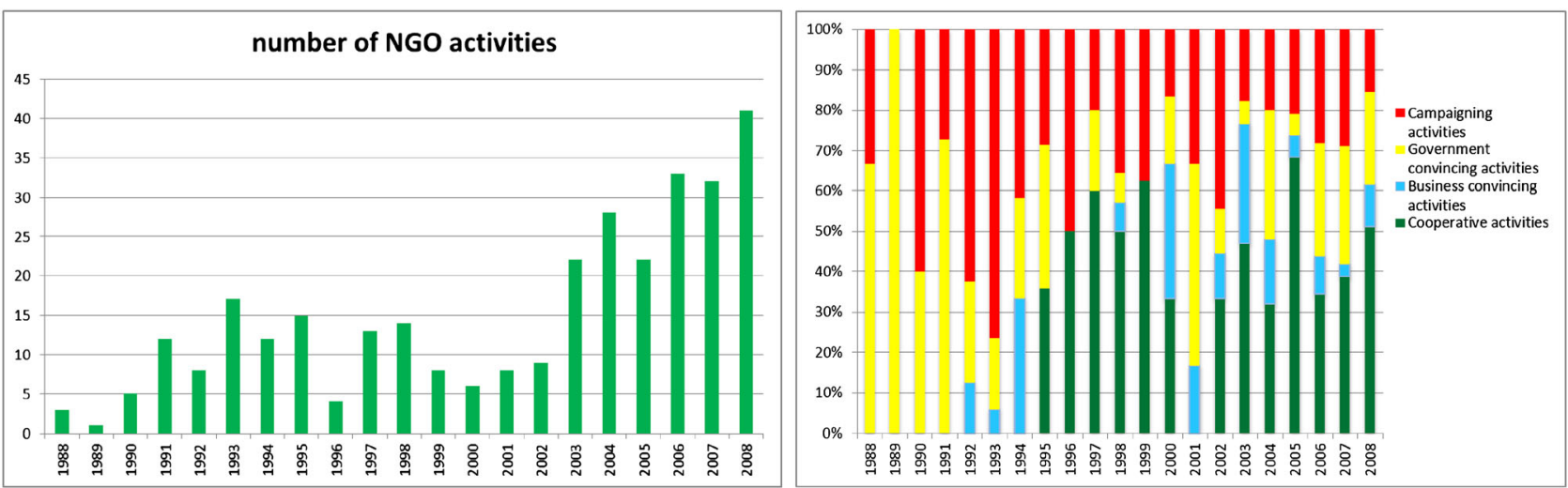

Figure 2. Absolute numbers and relative distribution of Dutch NGO strategic activities towards timber, mango and cocoa supply chains 
the Netherlands various television programmes have started to investigate business claims of sustainability or social responsibility. For a television show it works quite well if it is possible to find any non-conformity with such claims, and publicly express a verdict if any aspect of these claims seems to be unproven. In a study on such attacks on Tesco, the supermarket chain in the UK, we illustrated (Muller et al., 2009) that this is a fight that cannot be won if firms do not try to anticipate such public exposure in advance and try to prevent reputational damage.

The second collaborative strategy of NGOs may offer opportunities to prevent such reputational damage. The Dutch Association of Investors for Sustainable Development (VBDO) is an example of this: it publishes an annual benchmark of supply chain management every year but is also active in stakeholder engagement with their target firms (www.vbdo.nl). I will discuss other examples a little later.

\section{Reputational Damage}

Preventing reputational damage may be seen as a form of risk management, evaluating the maximum costs of such losses in consumer confidence against the chances of being exposed to severe attacks on irresponsible business behaviour. In the public discourse the concept of producer responsibility easily gets widely stretched to full supply chain responsibility. The recent debates and activities about the blind eye of the late Steve Jobs to the working and production conditions at his suppliers for the iPhone and the iPad, like Foxconn in China, illustrate this (Frost and Burnett, 2007; Kortelainen, 2008). Here one might say that these reputational risks strongly correlate with the size of the firm and with its closeness to the consumer, affecting those firms in the value chain that have the shortest links to consumers (Haddock-Fraser and Fraser, 2008). Yet it would not be wise for firms occupying more remote links in the value chain to ignore such risks, since once their buying brands are under attack, the damage will trickle down to them as well, as Foxconn is experiencing.

One line of defence here can be the argument that such storms will in the end pass over. This happened after the Shell/Brent Spar issue and the BP/Gulf of Mexico accident, as well as in many other cases. There is even scientific research supporting this position, showing that value losses on the stock market tend to evaporate quite fast (Engelen, 20II).

However, this mostly misses the point and ignores a wider implication of the macro-trends, which I discussed before. This is that workers, mid-level managers and CEOs of businesses are happy enough to appear to be more than only 'cool' short term profit and risk calculating economic actors. They have appeared to also have flesh, blood and a heart, and even may have a long-term vision. If a company's top level aspires in its mission statements to serve the market with quality products fulfilling genuine consumer and social needs, this core mission just does not match very well with receiving accusations of child labour, worker suicide, massive pollution of the Yellow River and so on.

In practice this opens the door for partnering in the second collaborative strategy of NGOs, as mentioned above. Firms with a developed long-term vision on sustainability do start to make friends and collaborate with the second group of civil society stakeholders. Civil society in itself exists as a large network of groups, showing a wide spectrum of greenness (Cleveland et al., 2005; Hopwood et al., 2005). It is in this playing field that firms will find partners with collaborative strategies (Cheung et al., 2009; Pinkhaar, 2010).

\section{Resource Wars}

There is another reason why addressing the global macro-threats merely with risk management misses the point. Mid-level managers and CEOs do not even need to have flesh, blood and a heart, but they need to use their eyes. Their sourcing and purchasing departments are their own connection to the macro threats discussed at the beginning of this paper. As shown, resource prices are rising strongly after decades of downward trends. Exports from Africa to Asia are strongly growing and exporters in Africa are in the position to shift from traditionally exporting to Europe to responding to often far more attractive offers from clients in Asia. The traditional resource base of Europe and North America is under pressure. This has recently also been recognized in the EU 2008 'Raw Materials Initiative' and the EU 2010 'Flagship Initiative for a resource efficient Europe'. In Europe one has to be aware that after two centuries of industrial society nearly all its own raw materials have been consumed, the European mines and gas bubbles are becoming empty. For European businesses this will imply they are facing higher resource costs, but are also 
losing parts of their supplier base. Firms that are using their eyes and are looking beyond the short-term issues are motivated to move to more collaborative approaches in their supplier-buyer relations and to participate in new forms of sustainable supply chain governance, which I will discuss later in more detail.

\section{Frontrunner Strategies}

However, the implications at the individual business level shown up to now are in principle still reactive, and defensive, mainly responding to outside pressures and threats. We can also see a fourth implication of these macrotrends. Businesses that go beyond the standard practices of looking to their first tier of the supply chain are able to see opportunities matching the triple goals of sustainability: both serving the planet and principles of fairness and responsibility and also sharing increased profit. Porter and Kramer have recently framed this with the concept of 'creating shared value', going beyond corporate social responsibility (CSR) based on philanthropy (Porter and Kramer, 20II). This concept combines the already classical claim of 'pollution prevention pays', with identifying opportunities to reorganize the global value chain by surpassing and cutting out rent taking links in the supply chain. They claim that once a firm acknowledges this potential and opens its eyes to opportunities for shared value creation, all essential links in the global value chain can get a larger part of a larger pie (Muller et al., 20I2; Ras \& Vermeulen, 20I2).

\section{What Types of Reactions do we See in Supply Chains?}

Let us now move from the implications for the working level of the 'factory floor' to what is happening at the level of full supply chains. What kinds of approaches are applied to address the remote environmental and community impacts?

Looking at the scene in the last decade, we can see four main generations of sustainable supply chain governance strategies (Welford \& Frost 2006; Vermeulen \& Seuring 2009; Vermeulen, 20I0; Driessen et al., 20I2, ):

I. do it yourself,

2. join forces and use third parties,

3. the 5 Cs approach - crossing sectors to cut costs and create critical mass,

4. Harmonizing to fight the confusion of tongues in Babel.

\section{Do It Yourself}

A typical palette of approaches is that of individual firms starting to work into their supply chains, often only connecting with the first tier, which is already a large enough assignment. Starting from the late I990s and early 2000 s brand owners and retailers started to use one or more of four tools in addressing the sustainability of their supply chain (Wycherley, I999; Seuring, 2004; Vermeulen \& Ras 2006; Carbone et al., 20I2):

- assessments of impacts with supplier questionnaires,

- demanding specific improvements,

- informing suppliers on impacts and improvement options; and

- developing firm-based codes of conduct in their procurement policies.

Thus approved suppliers were selected, while these selected firms often proudly reported these practices in their CSR reports (Preuss, 2005).

But mapping one's supplier base means that you have to cope with huge complexities, resulting in the following uncertainties:

- Do you really get control over your large supplier base of Iooos or I0,000s of interrelations, while also covering the full sequence of links, far beyond the first-tier approach?

- You may be running from issue to issue if you primarily respond to outside pressures; so, all-inclusiveness is needed, but how do you ensure you have addressed all impacts and issues? 
These considerations have various drawbacks: very high transaction costs, good supplier relations may be compromised and it is difficult to deal with the full complexity of sustainable development as an individual firm (the smaller the firm, the bigger the problem). But it is also problematic when we are looking from the reverse side: suppliers are overwhelmed with endless requests for supplier surveys, supplier evaluation etc. So, a logical step is to collaborate, which is our second strategy.

\section{Join Forces and Use Third Parties}

Increasingly, businesses collaborate with others in creating and participating in independent private standards, like the traditional Ecolabels, and more recent certifications like the FSC, Rainforest Alliance, MSC and so on. This growing number of private standards systems organizes supplier evaluation by developing detailed performance requirements and by using third-party control. In this way the costs of supplier selection can be externalized, because in most cases the suppliers will bear the cost of certification and the auditing costs (Ras \& Vermeulen, 2009).

This is a very interesting field of new forms of competition. In many specific product groups we see different private standards emerging in different countries and with diverging ambitions. We see Fairtrade and organic standards compete with mainstream market-based standards, applying different core philosophies and business models. Using a governance triangle (market-state-civil society) in describing the position of the various initiatives, Abbott and Snidal have shown that we see a clear shift from initially mainly government initiatives towards marketbased initiatives and more recently market-NGO collaboration (Abbott \& Snidal, 2009).

\section{The ${ }_{5}$ Cs Approach}

With the emergence of a large number of specific product certification schemes, a next step has been to create systems covering a broader scope of products. In this way the experiences of earlier systems, for example product A, have been copied into new systems for products D, E and F. Some examples of this are GlobalGap and Utz Certified, both initiated by major players in the retail market. Both have recently shown a very strong growth in the volume of sustainable certified products sold - up to $50 \%$ in the Dutch market. This can be described as a 5 Cs approach: crossing sectors to cut costs and create critical mass.

\section{Harmonization}

The ${ }_{5} \mathrm{Cs}$ approach was a first step towards harmonizing the various systems. But with systems originating simultaneously in various countries, suppliers and buyers are still facing a hugely complicated situation. Harmonization can be done via three routes: first, by mutual recognition between comparable schemes; second, by integrating various systems into a general worldwide standard; or third, by procedural harmonization.

Mutual recognition is standing procedure in the global market. Some examples of integrating into a worldwide standard can be found in the coffee market (with the CCC standard) and in the wine market, where the frontrunning New Zealand, Californian and South African standards have been the example for the OIV Guidelines for Sustainable Vitiviniculture of 2008 (OIV, 2008).

Procedural harmonization can be done in the form of setting a baseline for good governance of standards systems, like the 2006 ISEAL Codes of Good Practice for standards setting and for assurance, which were revised in 2010 and for impact assessment (ISEAL Alliance, 20IOabc).

\section{Is This Sufficient? Imagine 2022 - 10 Years After Rio $2012 \ldots$}

Let's now look back at the current global debate. In Rio de Janeiro the world community talked about a circular and fair global economy. It is fair to say that the business world has taken up the challenge during the last decade. Some corporations do this by acting in either of the three reactive modes, which we just discussed, while others are aiming to create shared value by advocating the fourth proactive approach. 
But, is a rapid and structural transition to a circular and fair global economy possible using this road of selfgovernance in the global economic arena? For this we need to look at the macro system level (see also Vermeulen, 20IO, p. I47): the total impact in a global market for a specific product chain, let's say clothing for example. The speed and reach of the adoption of these innovative supply chain governance approaches strongly depends on four key factors:

I. Is rapid growth of consumer demand possible?

2. Are these governance approaches 'all-inclusive'?

3. Are they successful in lifting up production practices of all suppliers to globally accepted levels of sound pollution prevention and globally accepted levels of social labour conditions and fair trading practices?

4. Do they address the major issues of unsustainability?

\section{Consumer Demand}

The consumer has been very reluctant in most countries in the last two or three decades (Vermeulen, 2002). In general, we see very small niche markets for sustainable goods. Businesses may use this as an excuse not to enter into the green market. However, seen from the perspective of green companies many success stories are available, because even gaining just a I\% market share is already a huge business case for a smaller individual firm.

But, far more then a few 'one per cents' are needed. Recently, we have seen some examples of major market breakthroughs. In the Dutch timber market and the coffee market, rapid diffusion of certified sustainable coffee to more than $50 \%$ market share has been achieved. This is a result of the emergence of competing certification schemes, some of these closely linked to the main actors on these markets (Kolk, 20I2; Vermeulen and Kok, 20I2).

But there are still tremendous challenges: a recent Dutch (Bron and van Amstel, 20II) study showed wide awareness of remote impacts such as child labor, low wages and overfishing $(80 \%$ of the consumers being aware of them, and $60 \%$ condemnatory), but very selective willingness to pay a bit extra (just a few per cent). In another recent study the Dutch organization for consumer information about sustainable products (Milieucentraal) showed that the large number of sustainability labels is not very helpful for getting the attention of consumers. The organization identified over roo different labels for consumer goods, but only one out of three consumers is able to spontaneously mention one or more of these labels! Here one should note that this in itself does not necessarily mean that products with these labels are not being sold, as I just showed for the case of timber and coffee. People do even buy sustainable products without knowing it.

Having many products with sustainability labels on the shelves can also still be fruitful for a firm's reputation, because they will also communicate their social responsibility practices in customer magazines, on websites and in annual reports. Yet, as noted already, here firms should be careful: such claims will only survive if one takes an all-inclusive and well-governed supply chain management approach.

\section{All-inclusiveness}

All-inclusive standards are needed for two major reasons:

I. Large market shares of sustainability labels will only be able to create positive supply side community and ecology impacts if they rest on clearly formulated and strict all-inclusive issue lists. These should simultaneously address all social and environmental issues acknowledged in the global community. However, the practice is very diverse, with a large number of narrow single-issue or few-issues standards. Environmental issues require an integrated approach, preventing a solution for problem X resulting in new problems $\mathrm{Y}$ and $\mathrm{Z}$ for other aspects or other places. To give an example, promotion of renewable biomass-based energy should not result in additional rainforest logging and competition for food in developing countries. The same reasoning is valid in addressing social issues in the supply chain.

2. For any business, both at the supply side and the demand side, it is a waste of time and money to run from media issue to media issue, like dolphin-free, carbon-neutral, child labour free, rainforest shaded and so on. Each of the narrow scope standard systems demand their own detailed certification and assurance information, requiring the organization of internal information management, creating additional participation costs. 


\section{Production Practices}

Next, it is essential to ensure effective improvement of remote production practices. Here, the general picture is quite blurred. We see a strongly growing number of scientific publications on effects in developing countries, some positive and some negative about the impacts. In most cases these are isolated case studies, missing a systematic analysis. One needs to distinguish three levels of effectiveness (Vermeulen et al., 20Io). Figure 3 illustrates this.

The first-order effects are the rules being followed and producer behaviour being adopted. The second-order effect is the reduced impact on environmental or social aspects resulting from this behavioural change: energy use is lower, emissions are lower, wages paid are in line with regulations etc. These should result in improvements in the ambient conditions: the ecosystem quality and community well-being. The third-order effects would be other (unplanned) effects. These can be both positive and negative. A positive example is what we found in Paraguay in organic cotton farming: farmer support training was also attended by non-certified farmers, who also implemented pesticide-free methods. A negative example could be the inability of many small farmers to get access to certification systems, or if they are audited and approved they may be unable to find exporters or retailers to buy their sustainable produce, in some cases even when they are collaborating in producer cooperatives (Nawrocka, 2008; Fayet and Vermeulen, 20I2; Illge and Preuss, 20I2). In practice the key actors rarely analyse the second- and third-order effects.

This lack of systematic research can well be explained by looking at the limited interests of the core actors in this market-place of self-regulation. The key issue here is that sustainable supply chain governance with codes of conduct and third-party certification to a large part rests on the principle of 'outsourcing the burden of proof. The core players are mainly interested in assuring first-order effects, which is organized in the systems by third-party auditing. For individual buyers and sellers this serves their needs. The core players either control themselves (self-assessment) or it is taken care of ('we are approved by the auditor'!). Additional control on this system of third-party control and on substantiating the second-order effects would require independent research by a fourth party. Private certification organizations need to keep their costs low, as they want to be able to be applied by as many firms as possible at both the supply side and the demand side of the value chain. Independent evaluation of second- and third-order effects of the full system would increase costs. Certification organizations can simply show their success by saying: 'Look at our growing numbers of approved firms/products'.

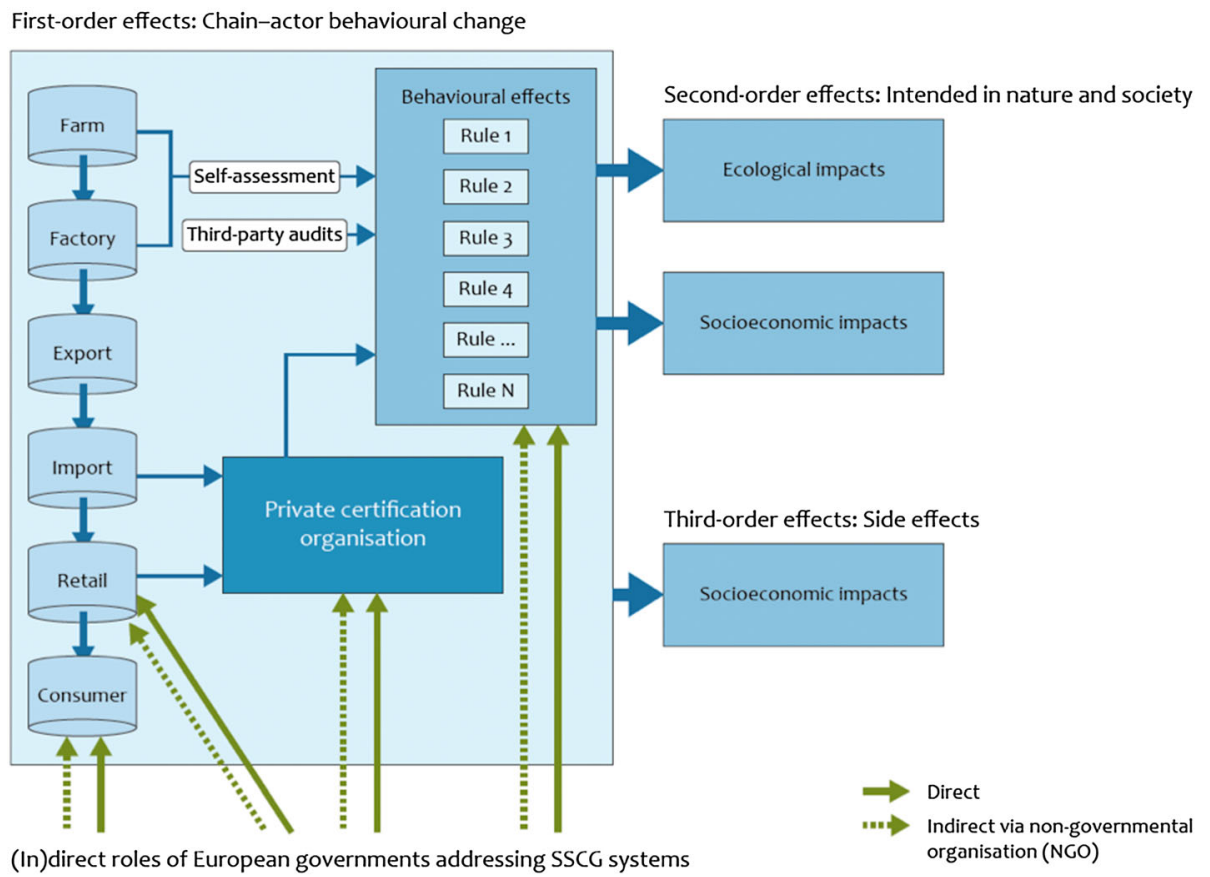

Figure 3. Evaluating outcomes, effects and impacts of sustainable supply chain goverance systems 
Meanwhile governments stand aside: they love self-regulating initiatives (Vermeulen et al., 20Iо; Vermeulen and Kok, 20I2). There may be some critical NGOs stepping into this vacuum, but their resources are very limited. We also see some academic initiative, but here also resources are the limiting factor. Recently a few meta-evaluations have been published comparing this research work (Alvarez and von Hagen, 20II; von Hagen and Alvarez, 20II; Alvarez and von Hagen, 20I2; von Hagen and Alvarez, 20I2; Barry et al. 20I2).

What we see here is that the very rationale behind the second and third generation of sustainable supply chain governance strategies is bouncing back to us: the rationale behind creating these private standard systems was to reduce the huge complexity for a single firm in assuring sustainability in its full supply chain. Systematic independent performance evaluation does not become established because of the same huge fourfold complexity; of the large supplier base; the sequence of supply chain links, far beyond the first-tier approach; reactive running from issue to issue; and the all-inclusiveness needed. This also makes systematic research on measuring impacts in the many different supplier countries and the many different product markets a difficult task.

Up to this point, we have discussed three of the four factors critical for creating impact, linked to the single firm or joint strategies on the supply side. More consumer support and well-governed, all-inclusive systems for specific products may create quite an impact, but more is needed.

\section{Major Issues Addressed}

Finally, at the system level, the ultimate issue is: does sustainable product certification really address the major persistent issues of unsustainability? At the beginning I briefly discussed them: population growth, poverty and food security; urban sprawl and unhealthy megacities; inefficient production and consumption accelerating depletion of crucial resources; carbon-based energy system and climate change; and ecosystem and biodiversity losses. As the main routes for solving these problems I referred to: creating a circular economy using few virgin resources; a shift to renewable resources; the UN Millennium Goals; bottom of the pyramid (BoP); and addressing institutional causes of unsustainability.

\section{Does it Work? At the Macro Level. . .?}

Returning to these macro-threats: would self-regulation with product standards substantially deal with these persistent issues and support the implementation of preferred solutions?

To answer this we first need to look at the limitations of this self-governance approach. At this moment there are at least three major weaknesses in this approach:

(I) We see a clear bias towards some types of products being addressed, most often those that are close to the main consumer requirements of food and clothing. Other domains of consumption, possibly taking a far larger share of the current and future social and environmental impacts of consumption, are not yet addressed or are just at the starting phase. Examples of these are household electronic equipment, large complex products like cars and various services, like the internet and telecoms.

(2) Many of the existing supply chain governance systems have a second bias with the tendency to mainly address the first links in the value chain, being farming or first production steps. Often the next manufacturing step is not included in the requirements, and modes and distances of transportation are in most cases fully ignored, but are often essential for determining a product's carbon footprint (Abbing, 20II).

(3) A third bias is that the certification programmes tend to focus on well-known environmental and social issues, with those which are new and emerging, such as resource depletion, being overlooked. The transition towards a resource-lean, fair economy requires individual businesses to re-evaluate their resource base. In practice this implies that at the input side the procurement function needs to address future resource scarcity and link to markets of recycled and remanufactured materials. And it implies that at the output side the product design function needs to emphasize 'design for sustainability' strategies, with special attention to choices in the use of material resources. Redesigning products based on the principles of design for sustainability and of shared value creation will shift the focus towards re-organizing the supply chain of products and their supply of materials and parts and to 
including issues of energy sources and distances and modes of transportation into the equation. Only with such an approach can the promises made by Porter and Kramer about all essential value chain partners getting a larger share of a larger pie possibly be lived up to (Porter and Kramer, 20II).

Governance of sustainability in global supply chains rests strongly on voluntary codes of conduct and certification, which are used as instruments of coercion in business-to-business interactions (Driessen et al., 20I2). Suppliers, as competing sellers, can hardly choose to ignore these buyers' wishes. The three major weaknesses just discussed can be dealt with if the global community of sustainable certification organizations addresses these and works towards a bottom line of good practice. The global organization ISEAL Alliance is already making steps towards this direction with their three codes of good practice.

Increasing the overall impacts of this form of self-regulation to the level of rapid and structural transition to a circular and fair global economy would require that these systems collectively:

- address all major impact product groups;

- are all-inclusive (issues and full chain);

- are well managed, open and transparent, fully monitored governance systems;

- are creating a practice of shared creation of value;

- have firms collaborating in redesigning their products/production processes.

So, in my view, more is needed here; the major weakness of the model of self-governance for sustainability in the global market is the lack of coordination and evaluation of goal achievement at the macro-system level. The crucial question then is: who could and would take the initiative on this level? There is a very limited role for governments here, also for supra-national governmental organizations. Remember that this self-governance actually came about as a response from front-running civil society actors and market actors in reaction to the regulatory vacuum in global markets, as briefly explained in the Introduction. Slow procedures and adversarial defence of vested sectoral and national interests are the problem here.

\section{What Would be the Ways Out of Here?}

In answering this we may very well be overlooking the obvious. I may be quite critical about the efforts being made in the market, but I am also optimistic. Analysing these practices I am pleasantly surprised about one interesting element of the developments we just evaluated; that is, the element of information exchange.

The fact is that, whichever of the four strategies discussed above (in What Types of Reactions do we See in Supply Chains?) are being applied, major businesses are interacting with each other concerning their joint environmental and social impacts at other places than just at their production sites. Many of us would not have believed this to be possible $20-30$ years ago.

This increased business-to-business interaction about externalities is in itself very remarkable and may very well hold the key to success. It implies that firms increasingly monitor and register their impacts. The first three strategies have a major disadvantage that, by using questionnaires, codes of conduct or certification audits, long lists of information about externalities are just translated into a simple YES or NO on each issue for procurement or certification decisions. In this way, creating, storing and exchanging information about social and environmental externalities does not link to the management cycle of continuous improvement.

In two ways, far better exploitation of the opportunities of information generation and exchange could boost the practices of sustainable supply chains: first on the firm-to-firm level, second on the system level.

At the firm-to-firm level, the YES or NO connected to a private sustainability standard and its logo is not useful and reliable for expressing a firm's or a product's real level of sustainability. It also does not provide any suggestions on how to improve. Here we can most probably make a big jump forward!

I am now talking about new work in progress, but the basic idea is that (going beyond simple life cycle assessment) we can use the new information now available because of the emerging business-to-business interaction about externalities to calculate the real price of a product, which would be the market price, plus the hidden costs 
(www.oiconomy.org). These hidden costs can be established using the principle of costs of prevention of each of the environmental and social impacts in each of the links of the value chain. This is possible for both environmental and social impacts. We will be calling them 'eco and social cost units' (ESCUs). This approach rests on practices in environmental sciences and ecological economics, which up to now have mainly been addressing shadow costs, or hidden costs on the national scale and on the scale of infrastructure projects. We are sure it can be applied to consumer goods in the international market as well.

With such full costs accounted for (market price plus hidden costs), the sustainability level of each product can also be shown, as an averaged sustainability level for each product in its full supply chain:

Sustainable performance level of a product $=\mathrm{I}-[\mathrm{ESCU} /(\mathrm{ESCU}+$ market price $)]$.

The higher the hidden costs, the lower the sustainability level would be, with a maximum of I. For each type of impact at each supply chain link the costs per unit of product for avoiding a specific negative impact can be known, using generally available knowledge about additional costs of alternatives for the current polluting or unethical practices.

What is possible now is to develop a system based on business-to-business enforced certification for an information exchange system. In this system each chain partner uploads its performance information per product unit about all relevant sustainability aspects to a data centre. This data centre applies a default knowledge base to calculate the ESCUs per aspect, per supply chain link, and aggregates the data into the full supply chain ESCU value. If any firm claims it has reduced any type of impact, it can demonstrate this by showing the improved technology or production system, the level of reduction and the prevention costs per unit. It will have lower ESCUs and thus a better sustainable performance level for the product. In this way the database is also a learning system collecting average costs of improvement technologies and options. The buyer can demand improvement or a fixed minimum performance level.

Participants are shown the ESCU per aspect and per link and also the possible prevention options not yet applied, with their impact on the total ESCUs. In this way it serves as a double learning system: first, showing the participating firms improvement options and secondly the system itself would be a learning system, annually adjusting the ESCU scores and the included improvement options. Such bi-directional information exchange would enable the creation of shared value.

At the system level we also see possibilities to create a performance assessment system that would enable continuous learning. Here we need to measure the impact of certification systems. Ideally an all-inclusive standard, addressing the relevant links in the chain, should be implemented with clear rules and regular independent compliance control. This would create a maximum impact, depending on the market share achieved by the value chain partners.

So, the performance of a certification system would equal the market share multiplied by its quality (which would be the product of 'scope', 'precision' and 'control intensity'). We have done some initial analysis on this, comparing the sequence of regularly adjusted certification requirements of the two most dominant certifications for sustainable coffee on the Dutch market, which are Fair Trade Max Havelaar and Utz Certified (Hueting \& Reijnders, I998; Metselaar and Vermeulen, forthcoming).

The analysis needed for this allowed us to show that the changes led to repeated improvements; it allowed us to compare the quality of the certification systems, which we called 'governance system performance', and by multiplying this with the market shares the product value expresses the expected impact in developing countries, which we called 'governance system impact potential'.

Further elaboration of the methodology and wide application can serve the knowledge needs at the system level for all the actors involved: the participating business, the certification organizations, consumers and their organizations and governments.

By further developing these two measurement systems we believe we can create more transparency - but far more important is, in both cases, that collecting the data needed for this offers direct opportunities to identify, exchange and get the connected actors to use the information about improvement options. This, in my view, is essential to make the step beyond self-governance in global supply chains as merely reactive and defensive responses to the major challenges on the global arena towards collaboratively creating shared value. 


\section{Conclusion}

In this paper we pose the question of whether the emerging practice of self-governance for sustainability in the global supply chains can deliver the impacts needed. Globalization of production and the emergence of an evergrowing wealthy middle class have made poverty, food security and biodiversity losses persistent threats. The emerging private standards addressing clean and fair production conditions in global supply chains have proved to be promising in creating impacts on the consumer side (growing market shares). Meanwhile, on the supply side, claims of success mostly rest on third-party assurance by auditors, merely demonstrating so-called first-order effects: compliance to standard requirements.

We then argued that some of the major limitations of this practice of self-governance are the lack of third-order evaluation and various biases due to the distributed responsibilities in the international field of market-based selfgovernance, with many creative and competing initiatives but no coordinating actor. The risk is that too many players in the field will just cause confusion and inefficiencies, and that major developments and needs will be overlooked. The challenge is to develop a form of 'meta'-governance, including new approaches by governments, combining public policy strategies with the demonstrated virtues of self-governance.

Front-running firms, already closely cooperating with NGOs, can play a trailblazing role in this. The firms described earlier as proactive frontrunners, applying shared value creation and newly established institutions, like the ISEAL Alliance, can take a role in addressing the biases we have discussed and experiment with approaches to create the interactive, self-learning systems suggested in the previous section.

\section{References}

Abbing, A.G. (2010) The Sustainability Performance of the South African - European Wine Supply Chain: Differences in sustainability from a scientific and actor perspective, Master's Thesis MSc Sustainable Development, Utrecht University, Utrecht.

Abbott, K.W. \& D. Snidal (2009) The Governance Triangle: Regulatory Standards Institutions in the Shadow of the State, in: W. Mattli \& N. Woods (eds.) The politics of global regulation 2009, Princeton University Press, p. 53.

Alvarez, G. \& Hagen, von O., 20II. The Impacts of Private Standards on Producers in Developing Countries. Literature Review Series on the Impacts of Private Standards, Part II, Geneva.

Alvarez, G. \& Hagen, von O., 20I2. When Do Private Standards Work? Literature Review Series on the Impacts of Private Standards; Part IV, Geneva.

Barry, M., Cashore, B. \& Clay, J., 20I2. Toward Sustainability. The Roles and Limitations of Certification, Washington.

Bron, P. \& M. van Amstel (20II) Duurzaam als basis en kiezen voor prijs, Duurzaamheidkompas \#6 thema: Een fatsoenlijke prijs (Sustainability as base and choose based on price, Sustainability compass, theme 6: a decent price), Market Response/Schuttelaar \& Partners, The Hague.

Caldwell, J.C. (2004) The Implications Of The United Nations Long-Range Population Projections. In: UN DESA (2004) World Population to 2300, New York, pp. II2-I23.

Carbone, V., Moatti, V., Vinzi, V.E. (20I2) Mapping Corporate Responsibility and Sustainable Supply Chains: An Exploratory Perspective. Business Strategy and the Environment, 2I (7), pp. 475-494.

Cheung, D.K.K., Welford, R.J., Hills, P.R. (2009) CSR and the environment: Business supply chain partnerships in Hong Kong and PRDR, China. Corporate Social Responsibility and Environmental Management, I6 (5), pp. 250-263.

Cleveland, M., Kalamas, M. \& Laroche, M., 2005. Shades of green: linking environmental locus of control and pro-environmental behaviors. Journal of Consumer Marketing, 22(4), pp.I98-212.

Dasgupta, P. (2010), Nature's role in sustaining economic development, Philosophical Transactions of the Royal Society B 365, 5-II.

Driessen. P.P.J., C. Dieperink, F. van Laerhoven, H.A.C. Runhaar and W.J.V. Vermeulen (20I2) Towards a conceptual framework for the study of shifts in environmental governance - Experiences and lessons from the Netherlands, Environmental Policy and Governance, 22, I43-160.

Engelen, P.J. (20II). Legal versus Reputational Penalties in Deterring Corporate Misconduct. In D. Sunderland \& M. Ugur (Eds.), Does Governance Matter? Governance Institutions and Outcomes (pp. 7I-95). Cheltenham: Edward-Elgar.

Escobar, A. (I996), Construction Nature: Elements for a post-structuralist political ecology, Futures, vol. 28, no. 4, pp. 325-343.

FAO (20II) State of Food and Agriculture 20I0-2011 (pp. 63-82).

Fayet L. and W.J.V. Vermeulen (20I2), Supporting Smallholders' To Access Sustainable Supply Chains: Lessons from the Indian Cotton Supply Chain, forthcoming in Sustainable Development.

Fischer-Kowalski, M., Swilling, M., (20II) Decoupling natural resource use and environmental impacts from economic growth, A Report of the Working UNEP Group on Decoupling to the International Resource Panel, UNEP.

Frost, S., Burnett, M. (2007) Case study: The apple iPod in China. Corporate Social Responsibility and Environmental Management, I4 (2), pp. IO3-II3.

Haddock-Fraser, J., Fraser, I. (2008) Assessing corporate environmental reporting motivations: Differences between 'close-to-market' and 'business-to-business' companies. Corporate Social Responsibility and Environmental Management, I5 (3), pp. I40-I55. 
Hopwood, B., Mellor, M. \& O’Brien, G., 2005. Sustainable development: mapping different approaches. Sustainable Development, I3(I), pp.38-52. Hueting, R. and L. Reijnders (I998), Sustainability is an objective concept, Ecological Economics 27, I39-I47.

IEA (20I0) World Energy Outlook 2010.

Illge, L., Preuss, L. (20I2) Strategies for Sustainable Cotton: Comparing Niche with Mainstream Markets. Corporate Social Responsibility and Environmental Management, I9 (2), pp. IO2-II3.

ISEAL Alliance (20IOa) Setting Social and Environmental Standards version 5.0, London, available online http://www.isealalliance.org/sites/default/ files/Standard-Setting-Code-v5.0.pdf (last retrieved I9-2-20I3).

ISEAL Alliance (20Iob) Assuring Compliance with Social and Environment Standards version 1.0, London, available online http://www.isealalliance. org/sites/default/files/Po4I_ISEAL_Impacts_Codevi.o.pdf (last retrieved I9-2-20I3).

ISEAL Alliance (2OIOc) Assessing the Impacts of Social and Environmental Standards Systems version 1.0, London, available online http://www. isealalliance.org/sites/default/files/Po4I_ISEAL_Impacts_Codevi.o.pdf (last retrieved I9-2-20I3).

Kolk, A. (20I2) Towards a Sustainable Coffee Market: Paradoxes Faced by a Multinational Company. Corporate Social Responsibility and Environmental Management, 19 (2), pp. 79-89.

Kortelainen, K. (2008) Global supply chains and social requirements: Case studies of labour condition auditing in the People's Republic of China Business Strategy and the Environment, I7 (7), pp. 43I-443.

Metselaar, J.A. and Vermeulen W.J.V (20I2) The performance of a Sustainable Supply Chain Governance System: a methodology for assessing the system performance and impact potential. Submitted to: Journal of Cleaner Production.

Muller, C., W. J. V. Vermeulen, et al. (2009) Perceptions on Demand Side and Realities on Supply Side: a Case Study on the South African Table Grape Export Industry. Sustainable Development I7(2009)5, pp. 295-310.

Muller, C., Vermeulen, W.J.V. and P. Glasbergen (20I2) Pushing or sharing as value driven strategies for societal change in global supply chains: two case studies in the British - South African fresh fruit supply chain, Business Strategy and the Environment, Vol. 2I, Issue 2, pp.I27-I40.

Nawrocka, D. (2008) Environmental supply chain management, ISO I4OOI and RoHS. How are small companies in the electronics sector managing? Corporate Social Responsibility and Environmental Management, I5 (6), pp. 349-360.

OIV, 2008. Guidelines for Sustainable Vitiviniculture, Verona: IOV.

Pinkhaar, S. 20I0. NGO strategies towards unsustainable supply chains. On the development of NGO strategies in the Netherlands towards timber, mango and cocoa supply chains, Copernicus Institute of Sustainable Development, Utrecht University, Utrecht.

Porter, M.E., Kramer, M.R., 20II, The big idea: Creating shared value, Harvard Business Review, 89 (I-2),

Preuss, L., 2005. Rhetoric and reality of corporate greening: a view from the supply chain management function. Business Strategy and the Environment, I4(2), pp.I23-I39.

Ras, P. and W. J. V. Vermeulen (2009). Sustainable Production and the Performance of South African Entrepreneurs in a Global Supply Chain. The Case of South African Table Grape Producers, Sustainable Development I7(2009)5, pp. 325-340.

Ras, P.J., and Vermeulen, W.J.V. (20I2) Innovative Business Cases in the South Africa Table Grape and Wine Industry's. Developing the Concept of Empowerment Entrepreneurship - forthcoming in World Review Of Entrepreneurship, Management and Sustainable Development.

Robinson, J. (2004) Squaring the circle? Some thoughts on the idea of sustainable development, Ecological Economics 48, 369-384 (I3 p.)

Schrader, C., Freimann, J., Seuring, S. (20I2) Business Strategy at the Base of the Pyramid. Business Strategy and the Environment, 2I (5), pp. 28I-298. Seuring, S. (2004) Industrial ecology, life cycles, supply chains: differences and interrelations. Business Strategy and the Environment, I3(5), pp.306-3I9. UNCED (1992) United Nations Conference on Environment and Development 1992, Agenda 2I, Rio Declaration, United Nations, New York.

UN DESA (2004) World Population to 2300, New York, pp. 4-9.

UN Millennium Ecosystem Assessment (2005) Ecosystems and Human Well-being. Synthesis (pp. 26-82).

UN Population Division (2010) Revision of World Population Prospects.

UNDP (20I0) The Millennium Development Goals Report 2010.

UNEP (20II) Towards a Green Economy: Pathways to Sustainable Development and Poverty Eradication, Geneva.

Vermeulen, W.J.V. (2002) The Stubborn Consumer. In: Driessen, P.P.J. \& P. Glasbergen (eds.), Greening Society. The Paradigm Shift in Dutch Environmental Politics, Kluwer Academic Publishers, Dordrecht, pp. 9I-III.

Vermeulen, W.J.V., 20I0. Sustainable supply chain governance systems: conditions for effective market based governance in global trade. Progress in Industrial Ecology, An International Journal, 7(2), pp.138-162.

Vermeulen, W.J.V., M.T.J. Kok, (20I2) Government Interventions in Sustainable Supply Chain Governance: Experience in Dutch Front-Running Cases, online in Ecological Economics.

Vermeulen, W.J.V. \& Ras, P., 2006. The challenge of greening global product chains: meeting both ends. Sustainable Development, I4(4), pp.245-256.

Vermeulen, W. J. V. and S. Seuring (2009). Introduction: sustainability through the market: the impacts of sustainable supply chain management. Sustainable Development I7(2009) 5, pp. 269-273.

Vermeulen, W.J.V., Y. Uitenboogaart, L.D.L. Pesqueira, J. Metselaar, M.T.J. Kok, (2010) Roles of Governments in Multi-Actor Sustainable Supply Chain Governance Systems and effectiveness of their interventions - An Exploratory Study, Bilthoven, Netherlands Environmental Assessment Agency (PBL)

Hagen, von O. \& Alvarez, G., 20II. The Impacts of Private Standards on Global Value Chains. Literature Review Series on the Impacts of Private Standards, Part I, Geneva.

Hagen, von, O. \& Alvarez, G., 20I2. The Interplay of Public and Private Standards: Literature Review Series on the Impacts of Private Standards, Part III, Geneva. WCED ig87. Our Common Future, Oxford University Press, Oxford.

Welford, R., Frost, S. (2006) Corporate social responsibility in Asian supply chains. Corporate Social Responsibility and Environmental Management, I3 (3), pp. I66-I76.

WTO ITS. WTO Statistics Database, Geneva, Assessed online at http://stat.wto.org/Home/WSDBHome.aspx (I2-6-20I2).

Wycherley, I. (I999) Greening supply chains: The case of the body shop international. Business Strategy and the Environment, 8 (2), pp. I20-I27. 